\title{
The Analysis of Classroom Character Education in English Lessons Based on the 2013 Curriculum
}

Ratih, I. A. M.

English Education Department, Ganesha University of Education dayutheyratih@gmail.com

\begin{abstract}
The study attempted to analyze the implementation of character education in the English lessons at SMP Negeri 1 Banjar. The subjects of the research were the eighth grade students and the English teacher. The researcher analyzed the lesson plans and the implementation to investigate how character education was inserted in the teaching of the four basic skills in English which has been integrated in the process of teaching and learning in 2013 curriculum. The instruments in this study consisted of interview guide, recorder, lesson plan analysis checklist, and observation checklist. Result of the analysis indicates that the teacher inserts the character values in indicators, learning materials, learning steps, and assessment instrument in lesson plans. In teaching and learning activities, character values are also implemented. However, the character values which are inserted in learning activities are different from one with another. It depends on the topic and indicators that will be achieved. In the evaluation, the strategies which were used by the teacher were in the form of advice and scoring rubric to assess character education in the process of teaching and learning.
\end{abstract}

Keywords: character education, english lessons

\section{Introduction}

Nowadays, Indonesia is facing many problems regarding deprivation of morality and character as an effect of globalization and poverty. Many social problems arise because of this phenomenon such as drug abuse, cyber-crime, rape, free sex, teen pregnancy, bullying, corruption, fight among students, plagiarism, cheating and so on. In accordance with this matter, education indeed plays an important role in developing good characters. Hence, the government has taken a step through education by inserting a program that is concerned about the improvement of good characters, namely character based education. Since the curriculum takes a big role in education, the government tries to implement character education through developing a character based curriculum which is known as 2013 Curriculum.

However, following the 2013 curriculum, teachers are required to integrate character education into their teaching learning processes. In this case, a model that promotes the integration of good values into classroom sessions is needed. Teachers are required to play the role of integrating good values suitable for their specific subjects into their teaching. Identifying an appropriate model for teaching good character fits with the aims of national education as pointed out in Indonesia's Constitution No. 20 of 2003 (Departemen Pendidikan Nasional, 2003) which, among other things, emphasizes the importance of teaching core values that are deeply rooted in religious and national culture, and the need to respond to current educational demands.

Suyanto (2009) stated that character is the way to think and behave of individuals which is to be a trick each individual to live and cooperate whether in the society, in family and in the country. It means that character is the main equipment to socialize in family, society and country, without character we can't survive in that situation. Character education in the 2013 curriculum are emphasized for purpose of balancing hard skills (cognitive and psychomotor) and soft skills (affective) of the students. Focusing the learning process in character building is important due to some negative phenomenon emerging recently, such as fight among students, use of drugs, corruption, plagiarism, cheating, and social unrest (Ministry of Education and Culture, 2013). 
In accordance with the character education purpose, the first core competency in the 2013 curriculum concerns on spiritual attitude which is respecting and internalizing their own religion. And then, the second competency is about attitude, in which it expects the students to respect and internalize behaviors which are honest, discipline, responsible, caring (tolerant, cooperative), well mannered, and confident in interacting effectively with the social and natural environment in society and its existence (Ministry of Education and Culture, 2013). Those competencies are related to character buildings.

Character education is very required in our life to educate the students to be better. Character education is a soul of education before the students get learning activity. Students should have strong character; teacher should be able to form the character by teaching the good values to the students. Generally, based on Indonesian Government Guidelines of Implementation of Character Education (2011), there are 18 values that have to be implemented. Then, the government formulates the values that have to be implemented especially in Junior High School level. These character values are deduced from religion, Pancasila, culture, and national education objectives, i.e. 1) religiousness, 2) honesty, 3) tolerance, 4) discipline, 5) hard work, 6) creativity, 7) independence, 8) democracy, 9) curiosity, 10) spirit of nationality, 11) nationalism, 12 achievement appreciation, 13) friendliness/communicativeness, 14) love of peace, 15) love reading, 16) environmental care, 17) social care, and 18) responsibility. The teachers chose the values that fit in with their lesson plans in accordance with the basic and core competencies that they taught.

English becomes the most-learned foreign language in Indonesia. It is a compulsory subject that is taught from the lower education level to the higher education level. Language is beneficial to teach good character by using good words and expressing the words in a good way. Therefore, character values can be developed through English subject. The character values development through English subject is expected to give a positive impact to the children and nation development.

Before integrating character values in teaching and learning process, the teacher should design lesson plans with character building included. A lesson plan is an extremely useful tool that serves as a combination guides, resource, and historical document reflecting our teaching philosophy, student population, textbooks, and most importantly, our goals for our students. The goals were not only in cognitive domain, but also in affective domain. Therefore, in order to implement character building in the teaching and learning process the adaptation of lesson plan is needed. The adaptation can be done by adding or modifying learning steps, indicator, and assessment technique so that character values can be implemented in teaching and learning process (Kemendiknas, 2010).

Some studies that have been done in other subjects by Yulia (2015) showed that character building was implemented in teaching and learning process. The first study conducted by Agustini (2014) showed that the teachers in Gugus 4, KecamatanBatujajar, Kabupaten Bandung Barat have already designed lesson plans with character values included. However, in the implementation of character building in the classroom, the teachers did not develop activities that accommodate the implementation of character building.

The other study by Dyudiarto (2013), showed that the implementation of character building in English subject at SMP Negeri Warungpring went well. However, the study showed that the teachers tended not to insert the character values in the lesson plan. The teachers preferred to implement the character values directly than develop character values in the lesson plan.

Concerning this matter, the researcher decided to analyze the implementation of character education in English lessons based on the 2013 curriculum at SMPN 1 Banjar. Starting from the academic year of 2013/2014, the Indonesian Government has mandated schools in Indonesia to start implementing the 2013 curriculum. SMPN 1 Banjar is one of the 
schools in Singaraja which is selected to implement the 2013 curriculum. SMPN 1 Banjar is located in Banjar village. It's not far away from the Singaraja city. Based on interview with the English teacher, the 2013 curriculum has been implemented for two years in SMPN 1 Banjar. During the implementation, there is no one ever conducting the study on the analysis of classroom character education in English lessons based on the 2013 curriculum.

This study focuses on describing and analyzing the implementation of character education in English lessons based on the 2013 Curriculum by English teacher of eighth grade students at SMPN 1 Banjar. Based on the observation, the researcher found some problems in this school at eighth grade students such as the students smoking, cheating and also one of the eighth grade students using tattoos in his body. It showed that, the moral values in the eighth grade students still need to be improved. The results of this study are expected to give a model of character building implementation.

\section{Methods}

This research aimed to investigate the implementation of character building in English subject. Thus, this research is qualitative. This study uses descriptive qualitative research since the setting and the data are natural. It means that there is no intervention from the researcher so that the events being observed are in the original condition (Bogdan\&Biklen, 1992:92).

As proposed by Bogdan\&Biklen there are five characteristics of qualitative research. First, it has the natural setting as the direct source of data and the researcher is the key instrument. In this study, the researcher entered the class and sat on the back row. The presence of the researcher did not affect the natural condition of the class, since the students in this school have been used to being observed by many researchers. Second, qualitative research is descriptive. The data collected is in the form of words or pictures rather than number. Three, it is concerned with process rather than simply with outcomes or products. Fourth, it tends to analyze the data inductively. Fifth, "Meaning" is essential to qualitative research.

This research were used to describe and analyze the implementation of classroom character education based on the 2013 curriculum by English teacher of eight grade students at SMPN 1 Banjar. The researcher analyzed one of English teacher regarding the implementation of character education in English lessons based on the 2013 Curriculum.

\section{Findings}

\section{Findings and Discussions}

\section{Finding from document analysis}

From the analysis of the lesson plans given by the teacher, the researcher found some characters that were planned to be implemented by the teacher. The first lesson plan, in the pre-activity contained the values of politeness, religiousness, and discipline. In the preactivity, the teacher planned some activities namely, greeting, praying checking students' attendance, and explaining the focus of the study. In whilst-activity teacher planned the characters of hard work, curiosity, logical thinking, honesty, independence, confidence, cooperative, creativeness, responsibility. In post-activity, the teacher planned to make summarized or conclusion, to make evaluation or reflection toward learning process, give homework, and close the learning activities. Here the characters of logical thinking, appreciativeness and politeness were planned. 
In the second lesson plan, in the pre-activity the teacher planned some activities namely, greeting, praying checking students' attendance, and explaining the focus of the study. In this activity the teacher inserted the character values of politeness, religiousness, and discipline. In whilst-activity teacher planned the characters of responsibility, creativeness, carefulness, independence, curiosity, logical thinking, friendliness/communicativeness, appreciativeness, honesty, hard work, and confidence. In post-activity, the teacher planned the characters of independence, friendliness/communicativeness, honesty and politeness.

The teacher also mentioned the character values in the lesson plan in the Indicator. The researcher could also find the elaboration of character values in the teaching material, learning activities and assessment.

\section{Finding from the observation}

After analyzing the lesson plans, the researcher did the observations to see the implementation of character building in English teaching and learning process. All observations were conducted in two meetings. Each observation was conducted in the same class in different material.

The first observation was done on Thursday, September 9th 2015. The class observed was Class 8.C. In the first meeting, the topic was about an oral and written text to state and ask about the ability and willingness to perform an action. During this meeting, the teacher taught the character values of politeness, curiosity, hardworking, independence, discipline, confidence, friendliness/communicativeness, logical thinking, appreciativeness, and honesty.

Table 1: The Character Values that were Implemented in the First Observation

\begin{tabular}{lll}
\hline & \multicolumn{1}{c}{ Implemented } \\
\hline Pre-Activity & Whilst-Activity & Post-Activity \\
\hline Politeness & Curiosity & Communicativene \\
Discipline & Discipline & ss \\
& Honesty & Politeness \\
& Confidence & \\
& Friendliness/communic & \\
& ativeness & \\
& Logical thinking & \\
\hline
\end{tabular}

The second observation was done on Thursday, September 16th, 2015. The class observed was Class 8.C. In this second meeting, the topic was about the expression to give and respond to the instructions and invitation. During the meeting, the teacher taught the character values of politeness, curiosity, think logically, friendly/communicative, honesty, independence, hardworking, confidence, discipline.

Table 2. The Character Values that were Implemented in the Second Observation

\begin{tabular}{lll}
\hline & \multicolumn{2}{c}{ Implemented } \\
\hline Pre-Activity & Whilst-Activity & Post-Activity \\
\hline Politeness & Curiosity & Appreciativeness \\
Discipline & Hard work & Honesty \\
Creativeness & Independence & Politeness \\
Confidence & Confidence & \\
\hline
\end{tabular}


Friendliness/commun

icativeness

Logical thinking

Respect

From the tables above, it can be seen that there were some different of the character values that were planned in the lesson plan and the character values that were implemented in the classroom.

\section{Discussions}

This descriptive study was conducted in SMP Negeri 1 Banjar. The subjects of the study were the English teacher and the students in VIII.C class in SMP Negeri 1 Banjar. The data were obtained from analyzing teacher's lesson plan by using lesson plan analysis checklist, observation by using observation checklist, and interview. In the finding above, the researcher has described (1) character values that were inserted in the lesson plan, (2) the character values that were inserted in teaching and learning process and (3) the teacher's way in assessing students' character values

As what stated in chapter II, there are eighteen character values that become the basis for data analysis in this section, namely religiousness, honesty, tolerance, discipline, hard work, creativity, independence, democracy, curiosity, and spirit of nationality, nationalism, achievement appreciation, and friendliness/communicativeness, love of peace, love reading, environmental care, social care, and responsibility.

The following discussion would give detail description about character values that were inserted in lesson plan, character values that were implemented in teaching and learning process, and the teacher's way in assessing students' character values.

\section{The Character Values that were Inserted in the Lesson Plans.}

Based on the findings, the teacher has designed lesson plans with character values. The characters were religiousness, confidence, responsibility, creativity, logical thinking, politeness, carefulness, independence, friendliness/communicativeness, curiosity, honesty, hard work, and discipline. Those characters were planned in the lesson plans.

In indicator, the teacher inserted the character values into the indicators in the lesson plans. The character values such as love of peace, tolerance, politeness, confidence, honesty, discipline, responsibility, and communicativeness were planned in the lesson plans.

In the learning materials, the teacher inserted the character values into the materials. In the first lesson plan was about oral and written text to state and ask about the ability and willingness to perform an action, the teacher inserted the character values in the form word and phrases. Communicativeness, social care and honesty were inserted. In the second lesson plan, the material was about oral and written text to give and respond to the instructions and invitation. In these materials, the teacher inserted the character values into the learning materials. There were four character values which were inserted, namely social care, communicativeness/friendliness, honesty, and politeness. In the materials, the teacher inserted the character values in directly and indirectly. It means the character values can be seen from the word uses and the content of the materials.

\section{The Implementation of Character Values in the Classroom.}

The teacher inserted the character values during teaching and learning process. In teaching and learning process there were three activities that should be done. Those were preactivity, whilst-activity, and post-activity. The teacher implemented character values on each activity. In order to analyze the data from the observations, the researcher classified the data based on the teacher's techniques for teaching character values. Some of the values were 
taught by using direct statements. Some other values were implicitly inherent in activities, not directly stated but inherent in asking students to do something and inferred by the students then confirmed by the teacher. As stated by Kemendiknas (2010) in Panduan Pendidikan Karakter untuk SMP, it is important for the teacher to make the students realize that they are in the process of building good character. One way to make the students realize that they are in the process of character building is by teaching the character values using direct statements. In this study, the character values implemented were not the same as those planned to be implemented by the teacher.

\section{The teacher's way in assessing students' character values.}

Based on finding above, the teacher integrated character education by some actions they did in teaching and learning process which actually most of their students did not notice. They did not clearly say or give examples to what characters which become objectives or listed on the lesson plan. Based on the observation, the strategies which were used by the teacher were in the form of advice and use scoring rubric to assess the students' characters.

From the findings, it was true that the English teacher of SMPN 1 Banjar have already implemented character building in the classroom even though some of the character values planned and the values implemented in the classroom did not match. Some of the values failed to be implemented in classroom, and some values beyond the values planned were implemented during the teaching and learning process.

Based on the theory from Lickona (2014), he had explained that school have the hope to form the character of students by using comprehensive approach in the classroom. In comprehensive approach, there were nine things that the teacher has done, namely act as tutor then role model and tutor, create moral community, practice moral discipline, create democratic class environment, teach values through curriculum, use cooperative learning, build "conscience in working", encourage moral reflection, and teach conflict resolution. In this study showed that the teacher was done two of them, namely teach values through curriculum and use cooperative learning.

First was "teach character values through curriculum". Lickona (2014) mention that teach character values through curriculum means that the character values were inserted or integrated and implemented in the lesson plan, materials, approach or strategy, and teaching and learning process in the classroom. In the following 2013 curriculum, teachers are required to integrate character education into their teaching and learning process. In this study explained that the teacher inserted the character values in planning, implemented the character values in the classroom, and evaluated the development of students' character. In this study showed that the teacher inserted the character values starting from indicator, learning material, teaching and learning step, and assessment. This study also showed that the character values were implemented during teaching and learning process. However, the process of character assessment, the teacher only used scoring rubric and gave advice for the students.

Second was "use cooperative learning". The teacher use cooperative learning to teach students about attitude of helping others and team work (Lickona, 2014). In this study explained that the teacher use cooperative learning by asked the students to work with their friends. In these activities, the teacher asked the students to work in pair in order to make the students can finish their work together. In these activities also can make the students helping each other to understand the topic or the material that was given.

Based on the empirical review, there were two researchers which made study about character values. First was Dyudiarto (2013). He was conducted a study concerning the implementation of character education on the 2013 Curriculum in SMP Negeri Warungpring. He analyzed about how the implementation of character education on the 2013 Curriculum. Second was Agustini (2014) conducted a study entitled "Implementasi Nilai-Nilai Karakter 
Dalam Pembelajaran Bahasa Inggris". Her study was conducted at VIII A6 in SMP N 1 Singaraja. The character values observed in her study were about religiousness, honesty, tolerance, discipline, hardworking, creativity, independence, democracy, curiosity, patriotism, and appreciation towards achievement, communicativeness, love of peace, love reading, conservation, social care, logical thinking, and responsibility.

From the empirical review and the result of this research, there were similarities between them. In empirical review, the researcher taught the character values starting planning, implementation, and evaluation. The similarities are that the teacher taught the character values by inserting and implementing the character values from planning, implementation, and evaluating students' character.

Building human being's character is not a simple task, since long process is needed. Besides, various approaches are needed to internalize the character values. Making the students realize that they are in the process of character building is also important so that it is possible for the students to assess themselves in the process of building their character. Therefore, teacher plays an important role to support the success of the implementation of character building in Indonesia.

Education has had two great goals: to help young people become smart and to help them become good." Good character is not formed automatically; it is developed over time through a sustained process of teaching, example, learning and practice. It is developed through character education. To be effective, character education must include the entire school community and must be infused throughout the entire school curriculum and culture.

Schools of character have one thing in common: a school-wide commitment to nurture the "whole child." They develop students socially, ethically and academically by infusing character development into every part of their curriculum and culture. Specifically, a school committed to character education explicitly names and publicly stands for specific core values and promulgates them to all members of the school community. They define the values in terms of behaviors that can be observed in the life of the school, and they model, study, discuss and use them as the basis for all human relations in the school. They uphold the values by making all school members accountable to consistent standards of conduct, and they celebrate their manifestation in the school and community. The key to success is that character educators are able to find what works in their particular school, district or community.

Formalized character education begins when members of a school, along with the broad involvement of community members, come together to determine the core ethical values that they share and form the basis for good education in their particular school. These values then become the foundation for all that the school does through curriculum, teaching strategies, school culture, extracurricular activities, etc.

Based on the findings and discussion, the researcher can concluded that the way the teacher taught character education were still commonly used by teachers in schools. It means that, there was no special technique that can be used by the teacher to implement the character education in SMPN 1 Banjar. Character education is not about how to teach the students about being polite or having good attitudes. But it is habituation or naturally happened to someone. Character can be formed by design or build good habits for the students. So they are able to behave and act based on the values that become their characters.

\section{Conclusion}

Dealing with the development of lesson plan that contains character education, it can be concluded that:

1. Teacher has inserted character values in the lesson plans. In the indicators, teaching materials, learning activities and assessment. In indicators, the character values can be 
seen from the use of the words which contained character values. In the learning materials, the teacher has inserted the character values. Then in the learning activities, the teacher planned the character values which will be taught in teaching and learning activities. Last is assessment. The assessment which used to assess students' character development was scoring rubric and gave the students advice.

2. The process of teaching and learning activities in the classroom, there were three activities that should be done by the teacher, namely pre-activity, whilst-activity, and post-activity. In each activity, the teacher implemented the character values. However, there were different character values which were emphasized for each meeting. Some of the character values planned and the values implemented in the classroom did not match. Some of the values failed to be implemented in classroom, and some values beyond the values planned were implemented during the teaching and learning process.

From the findings, it was true that the English teacher of SMPN 1 Banjar have already implemented character education in the classroom. However, the implementation of character education in SMPN 1 Banjar was still very commonly used by teachers in schools. There was no special technique that can be used by the teacher to implement the character education.

It is suggested that the Educational Authority give more guidance for the Educational Authority give more guidance for the teachers to implement the character education well. The guidance can be given by holding more workshops and seminars regarding the implementation of character education. The workshops and seminars should cover how to design lesson plans and how to implement the character education in English subject well. The Educational Authority should also distribute the guidance books of the implementation of character education more widely, so that the teacher can access the book easier. The workshops, seminar and guidance books are important media for the teacher to gain more knowledge to build students character.

It is also suggested that the school help the teachers to gain more knowledge in terms of character building. The school should also evaluate the implementation of character building in the school. It is also suggested that the school continue supporting the implementation of character building. English teachers are advised to gain more knowledge regarding how to develop lesson plans that contain character building. The knowledge they obtained can be a good reference to develop lesson plans containing character building and implement the values they have planned. It is also suggested for the teacher that they make the students realize that they are in the process of building characters, by using more direct statements in teaching character values, so that the students can sense the character building directly.

Further researchers are suggested to investigate other elements about the character education. They can possibly observe the techniques and assessment used by the teacher in implementing character education in the classroom.

\section{References}

Agustini, D. A. E., Tantra, D. K., Wedhanti, N. K. (2014). ImplementasiNilaiNilaiKarakterDalamPembelajaranBahasaInggris.JurnalPendidikandanPengajaran， 47, 123-134.

Bogdan, R. C. \&Biklen, S. K. (1992). Qualitative Research for Education: An Introduction to Theory and Methods. Boston: Allyn\& Bacon. https://apps.lis.illinois.edu/wiki/download/attachments/4366000/Field+notes.pdf?vers ion=1. Retrieved: October 6, 2015. 
Dyudiarto. (2013). The Implementation of Character Education on the 2013 Curriculum in SMP NegeriWarungpring. Retrieved November 14th, 2012.

Kemendiknas. (2006). "Kurikulum Tingkat Satuan Pendidikan." Jakarta: Kementerian Pendidikan Nasional Republik Indonesia.

Kemendiknas. (2013). "Kompetensi Dasar." Jakarta: Kementerian Pendidikan Nasional Republik Indonesia.

Kementerian Pendidikan Nasional. (2010). Panduan Guru Mata Pelajaran Bahasa Inggris Pendidikan Karakter Terintegrasi dalam Pembelajaran di Sekolah Menengah Pertama.

Kementerian Pendidikan Nasional. (2010). Pendidikan Karakter di Sekolah Menengah Pertama.

Lickona, T. (2014). Pendidikan Karakter: Panduan Lengkap Mendidik Siswa Menjadi Pintar dan Baik. Bandung: Nusa Media.

Pemerintah Republik Indonesia.(2003). Undang-Unadang Republik Indonesia Nomor 20 Tahun 2003.

Routledge.Bryman_Burgess.pdf.Retrieved: October 6, 2015.

Sugiyono, (2009).MetodePenelitianKuantitatif, Kualitatif, dan R \& D. Bandung: Alfabeta.https://deddysumardi.wordpress.com/2012/04/29/memahami-teori-dalampenelitian-kualitatif/

The Ministry of Education and Culture of republic of Indonesia.Retrieved December 2012.<http://www.kemdiknas.go.id/kemdikbud/>.

Yulia, A. (2015). The Integration of Second Core Competency (KI 2) of Curriculum 2013 in English Classes.Journal of English Language Teaching.English Department.Faculty of Languages and Arts.State University of Semarang. http://journal.unnes.ac.id/sju/index.php/elt. Retrieved: November 14th, 2012. 